\section{Australia puts idealism aside}

Canberra

WrTH the decision to lift the ban on uranium sales to France announced in the budget, uranium is once again a hot issue in Australia. The decision has infuriated the left wing of the Labor party. As they heard the decision announced three leftwing back benchers made an unprecedented protest by noisily walking out of the budget session. Outside parliament the decision triggered the resignation of one of Prime Minister Hawke's senior advisors and a vigil over a consignment of uranium in Darwin which protestors believe is destined for France. The Labor left have sworn to do everything they can to overturn the decision.

The ban was put in place in 1984 to protest at France's nuclear weapons test in

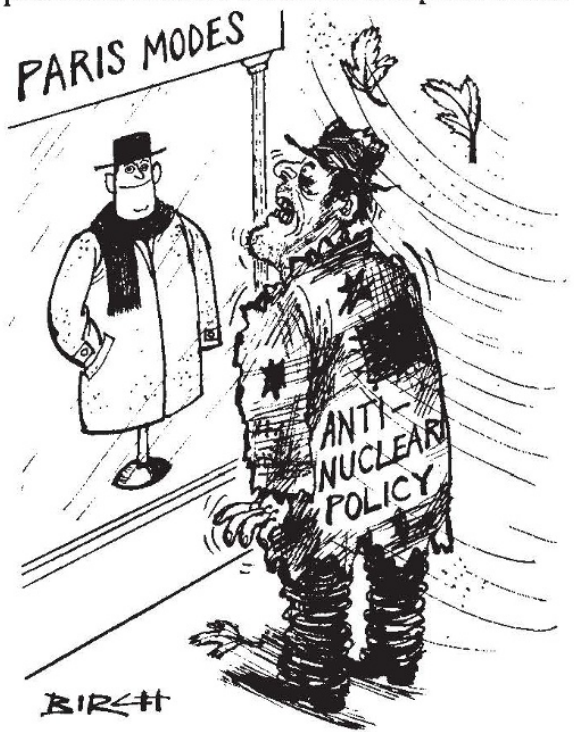

the South Pacific. The justification now given for revoking the ban is that it has had no effect. France continues to test in the South Pacific, they have been able to buy uranium more cheaply elsewhere, and Australia desperately needs the money. According to the Treasurer, Paul Keating, abandoning the ban will bring in $\$ 66$ million this financial year, helping right the country's woeful balance of trade.

Prime Minister Hawke's answer to the assertion by Labor's left wing that he must be bound by Labor party policy is that in times of economic crisis the government has the right to overturn party policy. Hawke's position was upheld by a 74-42 vote of the Labor parliamentary caucus. In an attempt to embarrass the government the Australian Democrats, who are represented in the Senate, have moved an amendment drafted directly from official Labor party policy banning uranium sales to France. If the amendment comes to a vote government members will have to join the opposition to vote for their own party's policy! The left is all the more

\section{European space programme}

angry because the budget pronouncement came only weeks after Labor's annual national conference, where the policy of banning sales to France was reaffirmed.

The ban was one of the last victories for the anti-uranium faction which was at its strongest while Labor was in opposition. But uranium has not always been synonymous with evil as far as the Labor party is concerned. The Whitlam government of the early $70 \mathrm{~s}$ was enthusiastic about its

potential as an export earner. The period even saw a visit by a government minister to Iran to try to sell uranium to the Shah. Since 1977 a series of compromises for the sake of miner's jobs and political expediency have reduced Labor's antiuranium policy to tatters. One compromise saw the opening of the Roxby Downs mine in South Australia, potentially the world's largest. Today Australia exports $\$ 300$ million worth of uranium per year. As Treasurer Paul Keating put it "when the Labor Party decided to mine Roxby Downs and let Ranger export, it decided not to have an anti-uranium policy".

Charles Morgan

\title{
Germany plans a space plane
}

\section{Hamburg}

FIRST Hermes, then HOTOL and now "Sänger". France and Great Britain have been joined by West Germany in proposing a totally new launch vehicle for the future space race with the United States and the Soviet Union.

Sänger, named after the German aerospace engineer Eugen Sänger, who died in 1964, is the result of joint work by Messerchmidt-Bölkow-Blohm and the German Aerospace Research Establishment and is based on ideas Sänger had back in the 1940s. The spacecraft is seen as lying in between Hermes, a small shuttle to be launched on Arian 5 (an upgraded version of the European Space Agency's rocket) and HOTOL, which requires the development of a new engine, working as a jet up to $30 \mathrm{~km}$ altitude and then turning into a rocket. The idea behind Sänger, considered by the United States before they fixed on the space shuttle, is to use a large $(50 \mathrm{~m}, 400$ ton) air-breathing, deltawinged hypersonic aircraft to carry a smaller winged orbital vehicle (length The German shuttle hitches a lift into space.
$25 \mathrm{~m}$, weight 50 tons of which 35 tons would be fuel) up to an altitude of $30 \mathrm{~km}$ and a speed of Mach 6. There the orbital vehicle's cryogenic engine would ignite and carry it into orbit; later it would land, like its mother plane, at a conventional aeroport.

The orbital vehicle would carry a crew of two, along with ten passengers and a cargo of up to four tons. Its designers claim launch costs would be a fifth of those calculated for Ariane 5. And the project would give Europe a chance to keep abreast with US plans for an "Orient Express" transatmospheric vehicle, for which more than 500 million dollars have been appropriated. Sänger's Mach 6 airbreathing plane could be converted to a passenger version capable of carrying 200 passengers more than $20,000 \mathrm{~km}$.

West Germany has asked the European Space Agency to study Sänger in parallel with HOTOL, its direct competitor. It is seen as a logical follow-on to Hermes which could fly by 1995 ; Sänger will not be ready before 2010 .

Jürgen Neffe

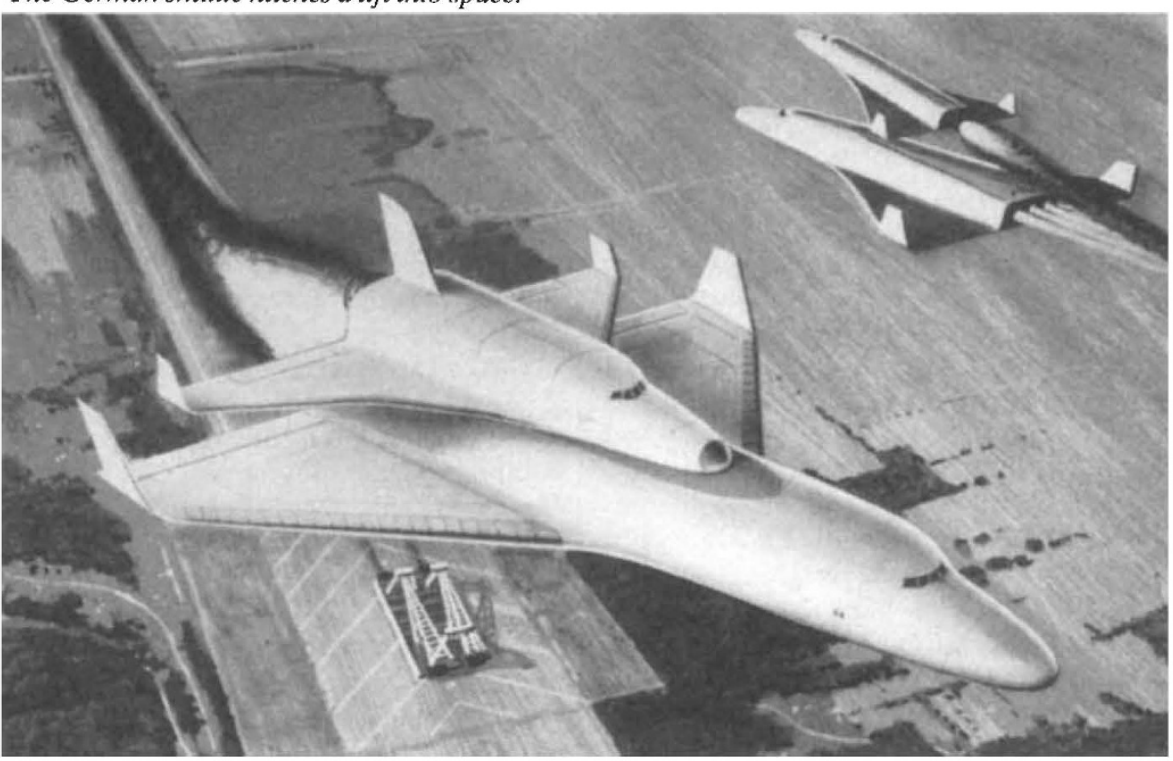

